\title{
REBELLEN MARTIN LUTHER
}

Heinz Schilling:

Martin Luther - rebel i en opbrudstid

Kristelig Dagblads Forlag, 2014

692 sider, $349,95 \mathrm{kr}$.

Heinz Schilling, der er professor emeritus fra Humboldt Universitet, har skrevet en omfattende, dybtborende og helt igennem velkomponeret Lutherbiografi. Schilling er i forvejen kendt som en habil og respekteret historiker, der har fokuseret på tidsfasen fra renæssancen og frem til 1600-tallet. Ud over at Schilling har været på hjemmebane, hvad angår temaet $\mathrm{i}$ bogen, har han brugt 10 års forskning på at nå frem til dette resultat. Bogen Martin Luther - Rebell in einer Zeit des Umbruchs udkom 2012, senere er fulgt flere oplag og endelig blev den hurtigt en international succes og er oversat til hovedsprogene. Og nu også dansk. Oversættelsen er foretaget af Peter Dürrfeld, og det er gjort imponerende flot, en oversættelse, der også får Schillings velskrevne tysk til at klinge på dansk.

Schilling sætter et dictum fra Goethe som overskrift for arbejdet. Det lyder: "Alle epoker, hvor troen hersker, i hvilken form det end måtte være, er strålende, hjertegribende og frugtbare, både for samtiden og eftertiden" - hvilket man nu godt kan anfægte, ikke mindst når man tænker på de sidste 30-40 år. Dog viser denne biografi, at, med Luther, kom troen atter i centrum i Europa som andet end kultisk udvendighed. Troen blev nu for alvor en eksistentiel størrelse - og der kom en epoke, hvor troen virkelig herskede. Hvorvidt det var strålende, hjertegribende og frugtbart kan man diskutere.

Bogen har selvfølgelig Luthers liv og virke i centrum, ja faktisk begynder den et par generationer før Luthers fødsel, hvor det vises, at det af Luther ofte i Tischreden fremførte billede af opvæksten som fattig minearbejde- og bondesøn, skal tages med store forbehold. Hans opvækst var ikke præget af fattigdom, dog heller ikke overflod. Herfra og hen over skole- og klosterår, opbruddet i 1517, bandlysning, bondekrige, konsolidering af protestantismen samt diverse splittelser inden for den nye bevægelse og frem til Luthers død, hvor reformbevægelsen havde opgivet at blive global og i stedet for var blevet regional følges udviklingen nøje, lige som det 
vises at Luthers oprindelige håbefulde optimisme til slut slår over i nedtrykt pessimisme. Nok er Luther i centrum, men det sker altid i en formidabel kontekstualisering og med et imponerende historisk overblik. Og nok er der sympati for og beundring af Luther, men på ingen måde distanceløs: hans stærke vilje og urokkelighed vises også at terminere i forstokkelse og blindhed fra tid til anden.

Noget af det mest slående ved denne historiografiske biografi er, at den viser enheden af den nye tro som temmelig klar og nydannende idésæt på den ene side, og så selve protestantismens indvævning i datidens politiske magtforhold og kampe på den anden side. For nok var selve budskabet klart og stringent, og tydelig markeret såvel overfor katolicismen som over for konkurrerende reformationsbevægelser, men samtidig var Luthers bevægelse præget af hans - vel rigtige - ide om, at hans reformbevægelse ikke kunne undvære øvrigheden, den kunne og skulle adskille sig fra den, men var samtidig i sin eksistens helt afhængig af den. Denne konstellation mellem religionen og politikken er bogens mest overbevisende budskab - og tillige det, der gør, at den meget kontekstorienterede historiografiske fremstilling har sin store berettigelse: Luthers reformation og dens resultater er ganske enkelt helt uforståelige uden blikket for dens afgrænsning til, men samtidig alliance med de politiske forhold i nærheden og så også i forhold til Europa i det hele taget, hvor også en - om man vil - lignende konstellation udfoldede sig mellem paven og kejseren. Ja, i det hele taget kan man sige, at hvis ikke fyrsterne i Luthers umiddelbare omgivelse havde beskyttet ham og hans reformation, var den sikkert kun blevet et historisk skvulp uden større betydning.

En anden ting, som Schillings fremstilling har så godt fat om er spændingen, ja kontrasterne mellem, hvad Luther ønskede og hvad han foranledigede eller gav anledning til både generelt samfundsmæssigt og kirkepolitisk. Her står den såkaldte sekulariseringsproblematik ganske tydelig i al sin kompleksitet: på den ene side en Luther, der skabte en ny form for eksistentiel og samvittighedsorienteret tro, som på en række måder kunne matche og stimulere nytidens individualisering og subjektivitet, på den anden side Luthers middelalderlige forestillinger om helt statiske samfund med klare og stivnede socialklasser og bånd. Og på den ene side en forestilling om adskillelse af tro og politik, og på den anden side troens indordning under politikken som beskytter og også agentur for udbredelse og fastholdelse. Eller: den intensive udbygning af universiteterne i de reformerte områder, universiteter med høj agtelse for lærdom og dannelse, og på den anden side ikke sjældent nærmest 
doktrinære afgrænsninger og pedantisk Besserwisserei. Eller: Luthers optagethed af humanismens sprogforståelse, og til dels nye syn på den klassiske litteratur, side om side med et fuldstændigt fravær af sans for renæssancens nye menneskesyn og den her frisatte subjektivitet. Eller: Luthers håb og ønske (i starten) om en ny global kristen tro contra (til slut) indretning af reformationen efter regionale retningslinjer og fronter. På mange måder gælder, at hvad der kaldes sekularisering ikke var noget mål for Luther, men det blev en uundgåelig effekt af hans virke.

Et tredje forhold, som der sideløbende gøres godt rede for er, at ikke bare frembragte Luther en reformation, han gav samtidig startskuddet til, at der med en vis grad af sandhed kan tales ikke bare om en katolsk modreformation, men egentlig også om en katolsk reformation. Det er et forhold, som i dag måske ikke er nyt at fremdrage, men Schillings fremstilling dokumenterer påstanden ganske overbevisende.

Et fjerde forhold, som bogen udmærker sig ved er dens påpegning og påvisning af den dynamik, som Luthers eskatologiske teologi afstedkom i hverdagen: Den bandt hverdagen og frelsehistorien sammen til en enhed, hvor det verdslige blev en del af frelsen, hvilket bl.a. betød at ægteskab, seksualitet, arbejde og politik blev opgraderet og fik ny legitimitet. Et forhold der både i det private og det offentlige liv frigjorde en dynamik, som under middelalderens fremherskende præstationsfromhed havde været unddraget verden.

Og så er der die Judenfrage, som også behandles med forståelse og afstandtagen. Luthers forhold til jøderne forandrede sig ganske voldsomt fra begyndelsen af reformationen til slutningen af den. I begyndelsen var han af den overbevisning, at jøderne lod sig omvende og skulle omgås som potentielle kristne - i slutningen skelnede han ikke mellem jøder og tyrkere, som på det tidspunkt udgjorde en påtrængende trussel mod Europa og kristenheden. Det er ikke overdrevet at kalde den gamle Luthers forhold til jøder et forhold præget af blindt og forblindende had - men, som Schilling også viser, var dette et had, der ikke - bortset fra selve hadets glød - havde noget at gøre med nazisternes racistiske jødehad. Luthers had var sikkert lige så stærkt emotionelt, men det havde ingen racistiske rødder - og det kunne således inddæmmes. At være jøde var et religiøst forhold ikke et skæbneagtigt blodsforhold.

Selv om denne biografi er historiografisk og ikke litterær formår Schilling at tegne et overbevisende billede af Luthers sproglige genialitet - og hans formidable 
produktivitet, som ikke er overgået af nogen anden tysker: Det blev statistisk set til ikke mindre end 1800 tryksider om året i en meget lang periode. En produktivitet der selv med nutidens skrivemuligheder også bliver svær at slå. Hertil kommer, som Schilling oplysende gør opmærksom på, at Luther insisterede på forbindelsen mellem boglig dannelse og kristen tro - noget, der absolut ikke var i højsædet i flere af reformationsbevægelserne. Han gav også anledning til, at dannelseskulturen kom ud til om ikke folket, så dog borgerskabet på en helt anden og effektiv måde end den klassiske humanisme havde gjort. Og endelig kan hans indflydelse på det tyske sprog ikke overvurderes, ikke bare på grund af bibeloversættelsen, men langt mere generelt.

Schillings biografi er netop en historiografisk biografi - ikke en idéhistorisk, filosofisk, kirkehistorisk eller teologisk afhandling. Men den kan med udbytte læses $i$ alle disse fagområder. Det er egentlig underligt: På den ene side er der meget lidt direkte filosofi i bogen. Således er Aristoteles end ikke nævnt i personregisteret (om end hans navn faktisk optræder en gang i selve teksten). Og når man ved, at Luther var arg Aristoteles-modstander, angiver det lige som omfanget af den direkte filosofiske komponent i værket. På den anden side er det ikke et direkte savn, for selv om Luther som filosof her er helt underspillet, ja nærmest overset - hvilket der i øvrigt et en substantiel tradition for - så lever man med det, al den stund Luthers religiøse tankeverden præsenteres ganske klart og overbevisende.

Et lidt længere citat fra bogens slutning kan vise dens klarsyn og næse for Luthereffekten: "Det sætter frembruddet af den nyere tid i Europa i et forkert lys, hvis man som følge af Luthers kamp mod autoriteterne betegner ham som revolutionær, men til gengæld nedvurderer hans fokusering på religionen og den konfessionelle epoke i Europa, der blev et resultat heraf, ved at opfatte den som et tilbageskridt i forhold til renæssancens rationalitet og frihed. Tværtimod: Idet Luther konsoliderede religionen, som en oprindelig og egen kraft, der hverken skulle tjene filosofi eller kunst, og pegede på at man skulle leve efter den og forsvare den ude i verden, frigjorde han en dynamik, der kom til at bidrage væsentligt til den sekulære omformning af Europa i begyndelse af nyere tid. - og i det lange løb også den moderne epokes frembrud" (s. 603).

Hans-Jørgen Schanz 